\title{
Neurovascular Compression Syndrome after Coiling Intracranial Aneurysm
}

\author{
Backhaus $\mathbf{R}^{1 *}$, Kremmler $L^{1}$, Kirzinger $L^{1}$, Wendl $C^{2}$ and Schlachetzki $F^{1}$ \\ ${ }^{1}$ Department of Neurology, University of Regensburg, Universitätsstrasse 84, 93053 Regensburg, Germany \\ ${ }^{2}$ Department of Radiology, University of Regensburg, Universitätsstrasse 84, 93053 Regensburg, Germany
}

\begin{abstract}
Objectives: Endovascular treatment of intracranial aneurysms using detachable coils is an established method by interventional radiologists. Next to prevention of subarachnoidal hemorrhage, prospective and retrospective studies have shown relief of symptoms caused by the mass effect of the aneurysm following this treatment.

Patients and methods: We present cases of endovascular treated intracranial aneurysms in patients developing focal neurological symptoms due to a local perianeurysmal inflammation. Furthermore, we review the literature to increase awareness of this complication, its pathophysiology and therapeutic options.

Results: Only rare cases of local perianeurysmal inflammation have been reported in literature. Clinical symptoms are heterogenous, up to focal seizures or symptoms of acute hydrozephalus. Pathophysiological, thrombembolism, local inflammatory and mass are possible aetiological factors. However, overall long-term prognosis is good.
\end{abstract}

Conclusion: Neurovascular compression syndrome after intracraniel aneurysm coiling is a rare and possibly delayed complication. With regard to various causes, diagnostic and therapeutic options should be considered.

Keywords: Neurovascular; Intracranial aneurysma; Inflammatory; Vertebrobasilar circulation

\begin{abstract}
Abbreviations: ADC: Apparent Diffusion Coefficient; CSF: Cerebrospinal Fluid; CT: Computed Tomography; CTA: Computed Tomography Angiography; DSA: Digital Subtraction Angiography; DWI: Diffusion-Weighted Imaging; FLAIR: Fluid Attenuated Inversion Recovery; FLASH: Fast Low Angle Shot; IV: Intravenous; MCA: Middle Cerebral Artery; MRA: Magnetic Resonance Angiography; MRI: Magnetic Resonance Imaging; PCA: Posterior Cerebral Artery; rtPA: Recombinant Tissue Plasminogen Activator; TCD: Transcranial Doppler Sonography; TOF: Time-of-Flight
\end{abstract}

\section{Introduction}

Endovascular treatment of aneurysms using detachable coils has evolved as a preferred alternative to classical surgical clipping to prevent rupture and subarachnoidal haemorrhage. For aneurysms located within the vertebrobasilar circulation, in particular, this treatment is first choice. Coil-induced closure of the aneurysm sac finally may reduce the lesion's mass effect on surrounding tissue with a consequent reduction in neurological symptoms, if symptoms due to mass effect occurred. Most reported complications of endovascular coiling include coil displacement, aneurysm rupture or puncture, artery dissection, and cerebral embolism. Only anecdotal information exists on progression of aneurysm size, local inflammation, and abscess formation after endovascular treatment. First, we present the case of a 49-year-old woman in whom a complex set of complications arose after aneurysm coiling and discuss current views on the subject and possible therapeutic options for rare side effects. In a second case we report about a 62-year-old man suffering from reduced consciousness, hemiparesis and dysarthria about three weeks after successful coiling of two intracranial aneurysms.

\section{Patients and Methods}

Case 1: A 49-year-old woman was admitted to the hospital for mild right-sided hemiparesis due to an ischemic stroke in the subcortical white matter of the left hemisphere, which was classified as a lacunar stroke.
During a diagnostic workup an asymptomatic aneurysm of the basilar artery was found (Figure 1). Diagnostic intra-arterial digital subtraction angiography (DSA), performed before interventional treatment, revealed that the aneurysm measured $9 \times 6 \mathrm{~mm}$ and was accompanied by a small daughter aneurysm. Coils were placed in successful in both aneurysms. At the end of the procedure, a small coil loop could be seen to protrude from the larger compartment overlapping the small side aneurysm (Figure 1). Eight hours after the intervention the patient developed bilateral mydriasis, which was followed by a progressive loss of consciousness. Emergency cerebral CT scanning with CTA ruled out the presence of aneurysm bleeding or ruptures but showed partial obliteration of the $\mathrm{P}_{1}$ section of both posterior cerebral arteries (PCAs). IV treatment with the gpIIb/IIIa inhibitor (tirofiban) was introduced. Immediate DSA confirmed the findings of the CTA with intraluminal sparing of contrast media, which were suggestive of fresh thrombotic material in both PCAs (Figure 2). After local thrombolytic treatment with $4 \mathrm{mg}$ rtPA, the patient recovered well. MRI revealed multiple small ischemic lesions with haemorrhagic transformation within the cerebellum and PCA territories; however, the patient showed no neurological deficits and was discharged from the hospital 5 days later. The patient was sent home on a regimen of acetylsalicylic acid $(100 \mathrm{mg} /$ day) and low-molecular-weight heparin (certoparin) for thrombosis prophylaxis. One week later the patient presented at the emergency room with progressive headaches and undulating double vision as well

*Corresponding author: Dr. Roland Backhaus, Department of Neurology, University of Regensburg, Universitätsstrasse 84, 93053 Regensburg, Germany, Tel: 0941-941-0; E-mail: Roland.backhaus@gmail.com

Received May 31, 2017; Accepted June 26, 2017; Published June 29, 2017

Citation: Backhaus R, Kremmler L, Kirzinger L, Wendl C, Schlachetzki F (2017) Neurovascular Compression Syndrome after Coiling Intracranial Aneurysm. J Vasc Med Surg 5: 319. doi: 10.4172/2329-6925.1000319

Copyright: (c) 2017 Backhaus R, et al. This is an open-access article distributed under the terms of the Creative Commons Attribution License, which permits unrestricted use, distribution, and reproduction in any medium, provided the original author and source are credited. 
Citation: Backhaus R, Kremmler L, Kirzinger L, Wendl C, Schlachetzki F (2017) Neurovascular Compression Syndrome after Coiling Intracranial Aneurysm. J Vasc Med Surg 5: 319. doi: 10.4172/2329-6925.1000319
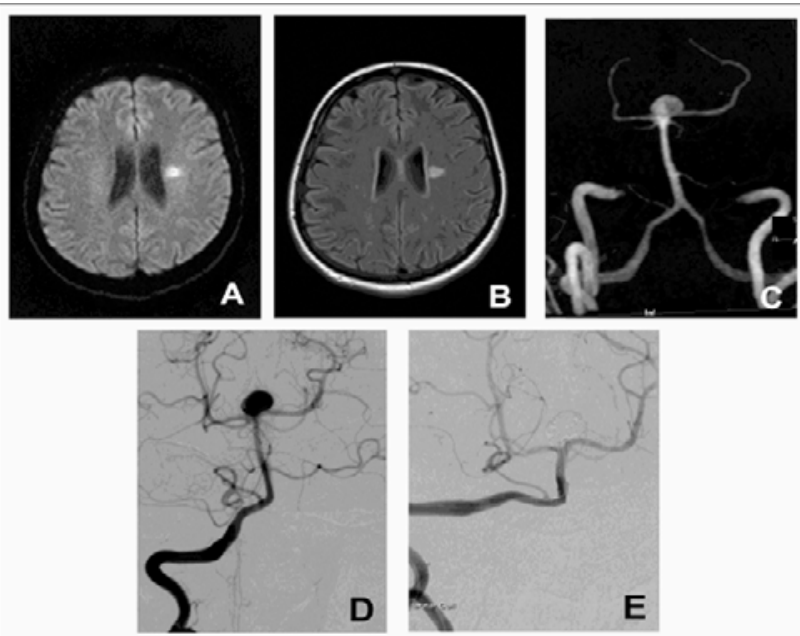

Figure 1: First case: 49-year-old woman after lacunar stroke (Figure $1 \mathrm{~A}+\mathrm{B}$ ) with two-asymtomatic aneurysm of the basilar artery (Figure $1 \mathrm{C}+\mathrm{D}$ ). After coiling of both (Figure 1E) the patients developed bilateral mydriasis and loss of consciousness.
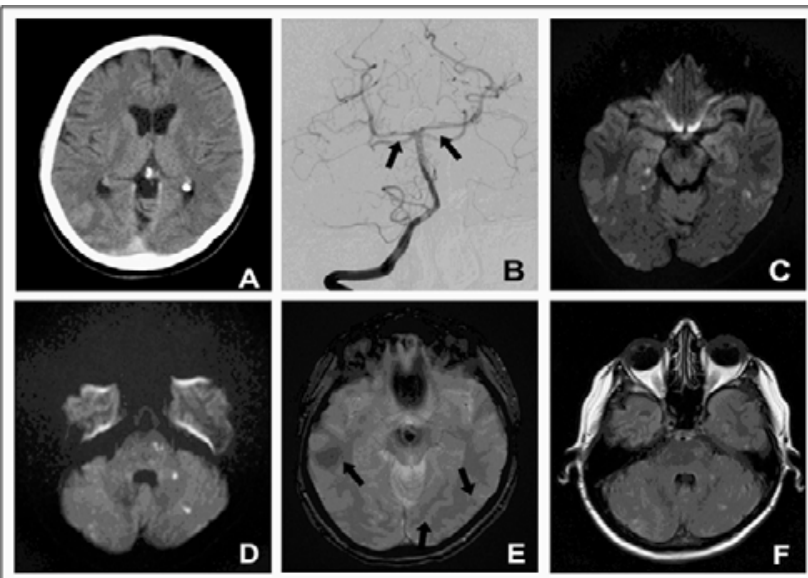

Figure 2: Native CT scan ruled out intracranial bleeding (Figure 2A). DSA and $\mathrm{MRI}$ scan revealed ischemic lesion in vertebrobasilar territory, PCA (Figure $B-F)$.

as right-sided mydriasis (Figure 3). A complete workup showed only a mildly elevated red blood cell count in CSF obtained from lumbar puncture and no sign of a disturbance in the blood-brain barrier. MRI revealed mesencephalic oedema on FLAIR sequence without changes on DWI or ADC (Figure 4). Over the course of the next week, the patient's double vision worsened due to left-beating nystagmus (Figure 3). Despite escalated anti-inflammatory and anti-oedematous therapy consisting of steroids and glycerol, follow-up MRI showed progressive mesencephalic oedema and, finally, evidence of ischemic stroke (Figure 4). The patient's symptoms gradually stabilized. She was transferred to a neurological rehabilitation centre with persistent double vision and was given antithrombotic therapy consisting of clopidogrel and certoparin. At the 3-month follow-up examination, the woman's oculomotor palsy was no longer detectable, but her intermittent double vision while looking to the left still persisted (Figures 3C and D). MRIs indicated a small post-ischaemic mesencephalic defect with no further evidence of oedema.

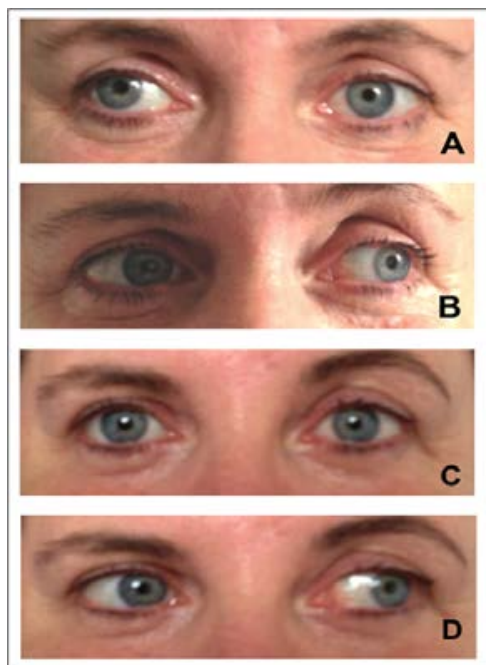

Figure 3: After one week undulating double vision and right sided mydriasis (A-D) without ischemic or inflammation correlate with the first MRI scan.
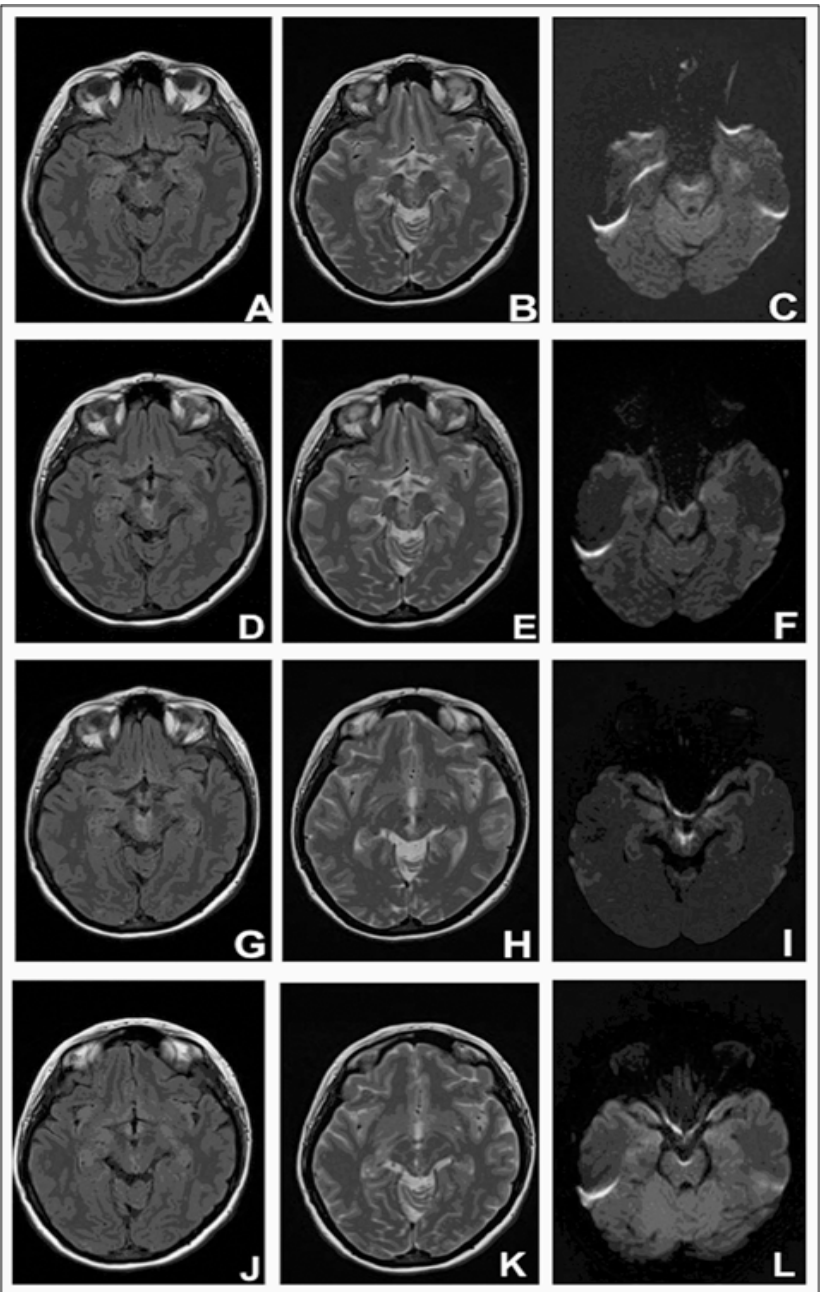

Figure 4: In follow up after one week with worsened symptoms enhanced mesencephalic oedema and ischemic stroke were seen (Figure 4A-L). 
Case 2: A 62-year-old male patient presented with reduced consciousness, right-sided hemiparesis and dysarthria. About three weeks before onset, two intracerebral aneurysms were coiled without complications, one at the top of the basilar artery (Figures 5A and 5C) and another at the left MCA (Figures 5B and 5C). CT scan was negative for intracranial haemorrhage. CSF was also negative for detection of haemorrhage, but showed elevated cell count. Empiric antibiotic treatment with a regime of ceftriaxone and ampicillin, later furthermore metronidazole and fosfomycin, next to an anti-oedematous treatment with methylprednisolone was initiated. In further work-up, MRI scan showed regular position of both coil packages and a local lesion nearby the coil of the left ACM aneurysm (Figure 5D). A new ischemic lesion could not be detected. After medical treatment over two weeks, clinical recovery and reduction of the inflammatory lesion in MRI were seen (Figure 5E). The patient was discharged after restitutio ad integrum. Occasional amnestic aphasia lasting for few seconds could be correlated with pathological EEG transformation over the left temporal lobe. Under medical treatment in a 5-year follow up, the patient presented stable results in clinical examination, MRI and transcranial ultrasound.

\section{Results}

The first post-interventional set of complications observed in the first patient still has not been explained satisfactorily. Enhanced clotting during the endovascular procedures and the primary stroke made us screen for a coagulation abnormality, which seems likely but nevertheless remains unproven. There was no thrombotic event in the patient's history nor in her family. All known and measurable coagulopathies including Fabry's disease were ruled out. The embolic pattern of the lesions on DWI and the fact that the lesions were located significantly below the aneurysm neck make it unlikely that the coils caused the thrombus formation. We therefore propose underlying endothelial hypersensitivity as a possible cause of the lesions, which would also reflect the early haemorrhagic transformation of these lesions as seen in (Figure 2E). Double vision lasting only for seconds to a few minutes is more likely explained by a malfunction of the third cranial nerve caused by pulsation of the coiled aneurysm; this is similar to the neurovascular compression syndromes known to occur with the $5^{\text {th }}$ cranial nerve. In $1991 \mathrm{Kwan}$ et al. reported an increase in aneurysm size due to what they called the "water-hammer effect" [1] of pulsatile blood flow from the basilar artery. In the present case there was no evidence

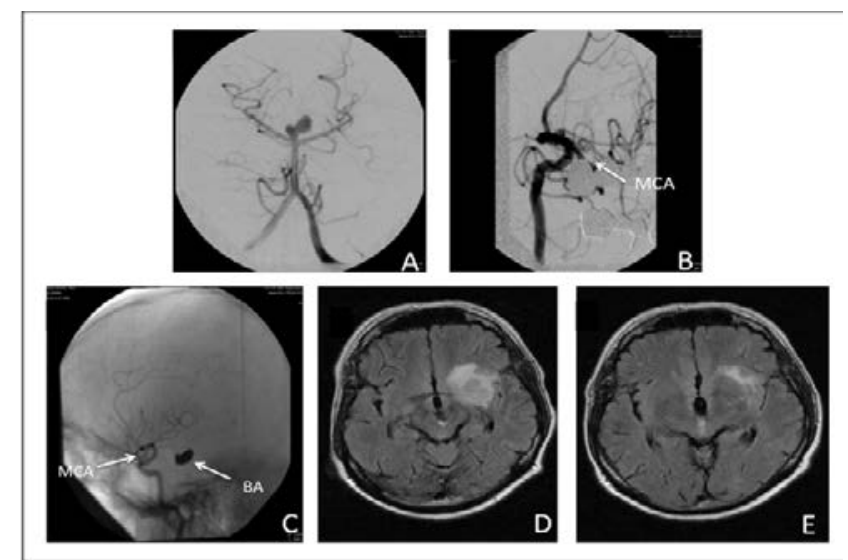

Figure 5: Case 2. 62-year-old patient with two intracerebral aneurysms one at the top of BA, another at left MCA (Figure 5A-C). Three weeks after coiling upcomin neurological deficites. MRI showed perianeurysmal inflammatory lesions responsive to antibiotic and antioedematous treatment. of an increase in aneurysm size, incomplete coil packing, or space between aneurysm and coils, which makes this hypothesis unlikely. We discussed the possibility of a neurovascular compression syndrome and were considering placing the patient on antiepileptic medication to treat her symptoms when the last set of complications began. Over time we observed progressive neurological symptoms, which could be explained by an impairment of the tractus lemniscus medialis. At that point in our diagnostic investigation, neurovascular compression as the sole pathological mechanism appeared unlikely. The damage to the tractus was best explained by local inflammation of the aneurysm wall leading to mesencephalic oedema. Horie et al. observed similar oedema, but in their patients the aneurysms had not been completely obliterated [2]. Overall, the precise mechanism leading to obliteration of an aneurysm is still unclear, with opposing data obtained in humans $[3,4]$ and mice [5] concerning the endothelium at the neck of the aneurysm (Table 1). Considering a normal response of thrombosis, the release of inflammatory cytokines after platelet activation [6] in a setting of critical-size of space occupying aneurysm could lead to an inflammatory response, which in turn leads to even greater thrombosis: $[7,8]$ a vicious circle of acute thrombosis and worsening of neurological symptoms. Treatment options in this case seem to be high doses of steroid medications, as reported by Stracke et al. [9]. In the first reported case the presumed inflammation proved to be sterile, with no evidence of bacterial contamination of the coil package [10] as confirmed by an analysis of the patient's CSF. In the end we believe that a small enlargement of the aneurysm following coiling first caused a neurovascular compression syndrome and, over time, produced mesencephalic oedema via sterile neurovascular inflammation. In the second case also an inflammatory lesion after coiling might be responsible for diverse neurological deficits. The combination of local inflammatory lesion in MRI with contrast enhancement and elevated cell count in CSF is also suspect of post-interventional abscess, which could not be excluded retrospectively. Elevated CSF cell count can be found in local inflammation as well. Finally, medical treatment with antibiotical and anti-inflammatory regime was successful. Possible reasons for neurovascular inflammation after coiling or implementation of other devices and stents might be contamination of the material, mechanical irritation or hypersensitivity.

However, only rare information about this complication exists in literature. Skolarus et al. describe white matter changes after aneurysm coiling and hypothesize an exuberant inflammatory response related to implementation of polyglycolic-polylactic acid coils, however, bioactive coils were not used in this case [11]. Despite escalating antiinflammatory and anti-oedematous therapies, the oedema persisted and eventually a small mesencephalic stroke occurred. Whether this stroke was caused by obliteration of small perforating arteries or traction of arteries due to the mass effect of the aneurysm, or whether it was due to direct compression or indirect compression resulting in venous congestion is speculative [12,13]. Especially in the first case obliteration of the aneurysm led to a more pronounced inflammatory mass effect. This is in contrast to the effect itself mostly described in the literature: Alleviation of compression by reducing pulsation of the aneurysm wall $[14,15]$. We were fortunate that we never were forced to consider the ultimo ratio treatment option-bilateral occlusion of the vertebral artery [16]. In addition, coil removal to prevent a progressive unstoppable mass effect was never part of our discussion $[17,18]$.

We reviewed the literature to see whether a surgical approach may have been a wiser treatment plan. We found no clear preference for surgical clipping or endovascular treatment with respect to the critical size of an aneurysm, localization of the lesion, or already existing 
Citation: Backhaus R, Kremmler L, Kirzinger L, Wendl C, Schlachetzki F (2017) Neurovascular Compression Syndrome after Coiling Intracranial Aneurysm. J Vasc Med Surg 5: 319. doi: 10.4172/2329-6925.1000319

Page 4 of 6

\begin{tabular}{|c|c|c|c|c|c|c|c|c|}
\hline Author & Case/study & Paper & Journal & year & Diagnosis & Treatment /problem & Treatment complication & \#pat. \\
\hline Cohen JE & Case & $\begin{array}{l}\text { Postembolization } \\
\text { perianeurysmal edema as a } \\
\text { cause of uncinate seizures. }\end{array}$ & $\begin{array}{l}\text { J Clin } \\
\text { Neurosci. }\end{array}$ & 2012 & $\begin{array}{l}\text { giant unruptured } \\
\text { supraclinoid } \\
\text { aneurysm }\end{array}$ & $\begin{array}{l}\text { endovascular } \\
\text { embolization, bare } \\
\text { coils and implantation } \\
\text { of a flow diverterstent }\end{array}$ & $\begin{array}{l}\text { Uncinated seizures, successfully } \\
\text { treated by steroids }\end{array}$ & 1 \\
\hline $\begin{array}{l}\text { Vu Dang } \\
\text { L }\end{array}$ & Case & $\begin{array}{l}\text { Post-embolization } \\
\text { perianeurysmal edema } \\
\text { revealed by temporal } \\
\text { lobe epilepsy in a case of } \\
\text { unruptured internal carotid } \\
\text { artery aneurysm treated with } \\
\text { bare platinum coils. }\end{array}$ & J Neuroradiol. & 2009 & $\begin{array}{l}\text { unruptured internal } \\
\text { carotid artery (ICA) } \\
\text { aneurysm }\end{array}$ & bare platinum coils & Seizures & 1 \\
\hline I. Craven & Case & $\begin{array}{l}\text { Symptomatic Perianeurysmal } \\
\text { Edema Following Bare } \\
\text { Platinum Embolization of a } \\
\text { Small Unruptured Cerebral } \\
\text { Aneurysm }\end{array}$ & $\begin{array}{l}\text { AJNR Am J } \\
\text { Neuroradiol. }\end{array}$ & 2009 & $\begin{array}{l}\text { relatively small } \\
\text { aneurysm }(7 \mathrm{~mm})\end{array}$ & bare platinum coils & $\begin{array}{l}2 \text { nocturnal seizures (tonic-clonic) } \\
\text { and further daytime complex partial } \\
\text { seizures }\end{array}$ & 1 \\
\hline $\begin{array}{l}\text { Fanning } \\
\text { NF }\end{array}$ & Paper & $\begin{array}{l}\text { Wall enhancement, edema, } \\
\text { and hydrocephalus after } \\
\text { endovascular coil occlusion of } \\
\text { intradural cerebral aneurysms. }\end{array}$ & J. Neurosurg & 2008 & $\begin{array}{l}\text { intradural cerebral } \\
\text { aneurysms }\end{array}$ & $\begin{array}{l}\text { bare platinum or } \\
\text { modified platinum } \\
\text { coils }\end{array}$ & $\begin{array}{l}\text { Asymptomatic aneurysm wall } \\
\text { enhancement perianeurysmal edema, } \\
\text { and hydrocephalus, occurred in } \\
18.6 \% \text { of embolizations performed } \\
\text { with bare platinum coils }\end{array}$ & 181 \\
\hline Misaki K & Case & $\begin{array}{l}\text { Unusual delayed } \\
\text { hydrocephalus after bare } \\
\text { platinum coil embolization of } \\
\text { an unruptured aneurysm. }\end{array}$ & $\begin{array}{l}\text { Neurol Med } \\
\text { Chir (Tokyo). }\end{array}$ & 2010 & $\begin{array}{l}\text { incidentally } \\
\text { detected } \\
\text { unruptured large } \\
\text { internal carotid } \\
\text { artery aneurysm }\end{array}$ & bare platinum coils & $\begin{array}{l}\text { wall enhancement and perianeurysmal } \\
\text { brain edema. hydrocephalus including } \\
\text { disorientation, gait disturbance, and } \\
\text { urine incontinence at } 7 \text { months post- } \\
\text { embolization }\end{array}$ & 1 \\
\hline Horie & $\begin{array}{l}\text { Case + } \\
\text { Review }\end{array}$ & $\begin{array}{l}\text { Progressive perianeurysmal } \\
\text { edema induced after } \\
\text { endovascular coil } \\
\text { embolization. Report of three } \\
\text { cases and review of the } \\
\text { literature. }\end{array}$ & J. Neurosurg & 2008 & & $\begin{array}{l}\text { endovascular coil } \\
\text { embolization }\end{array}$ & $\begin{array}{l}\text { progressive vasogenic brain edema } \\
\text { surrounding a cerebral aneurysm. } \\
\text { incomplete occlusion of larger } \\
\text { aneurysms may lead to a } \\
\text { disorganized intraluminal thrombosis, } \\
\text { aneurysm pulsing, and intramural } \\
\text { hemorrhage or inflammation }\end{array}$ & 3 \\
\hline $\begin{array}{l}\text { Marden } \\
\text { FA }\end{array}$ & Case & $\begin{array}{l}\text { Perianeurysm edema with } \\
\text { second-generation bioactive } \\
\text { coils }\end{array}$ & Surg Neurol. & 2008 & $\begin{array}{l}\text { unruptured, } \\
\text { nongiant, saccular } \\
\text { aneurysm }\end{array}$ & $\begin{array}{l}\text { embolization with } \\
\text { Matrix2 coils }\end{array}$ & perianeurysm edema & 1 \\
\hline $\begin{array}{l}\text { Stracke } \\
\mathrm{CP}\end{array}$ & case & $\begin{array}{l}\text { Severe inflammatory reaction } \\
\text { of the optic system after } \\
\text { endovascular treatment of a } \\
\text { supraophthalmic aneurysm } \\
\text { with bioactive coils. }\end{array}$ & $\begin{array}{l}\text { AJNR Am J } \\
\text { Neuroradiol. }\end{array}$ & 2007 & $\begin{array}{l}2 \text { aneurysms of the } \\
\text { right ICA }\end{array}$ & endovascular coiling & $\begin{array}{l}\text { after a symptom-free interval, } \\
\text { developed severe vision impairment, } \\
\text { extensive edema in the central } \\
\text { nervous tissue neighboring the treated } \\
\text { aneurysm }\end{array}$ & 1 \\
\hline $\begin{array}{l}\text { Deus- } \\
\text { Silva L }\end{array}$ & Case & $\begin{array}{l}\text { Severe aggressive } \\
\text { acute disseminated } \\
\text { encephalomyelitis-like } \\
\text { reaction after aneurysm } \\
\text { coiling }\end{array}$ & Neurosurgery. & 2010 & $\begin{array}{l}\text { incidental } 4 x \\
6-\mathrm{xm} \text { anterior } \\
\text { communicating } \\
\text { complex aneurysm }\end{array}$ & & $\begin{array}{l}\text { severe brain edema induced by } \\
\text { contrast media and resembling an } \\
\text { aggressive acute disseminated } \\
\text { encephalomyelitis-like reaction with } \\
\text { global aphasia, dysarthria, right } \\
\text { upper motor neuron pattern facial } \\
\text { paresis, and right hemiplegia and } \\
\text { hemianesthesia. }\end{array}$ & 1 \\
\hline Sim KJ & $\begin{array}{l}\text { Retrospective } \\
\text { analysis }\end{array}$ & $\begin{array}{l}\text { Intracranial aneurysms with } \\
\text { perianeurysmal edema: } \\
\text { Long-term outcomes post- } \\
\text { endovascular treatment. }\end{array}$ & J Neuroradiol & 2014 & & $\begin{array}{l}838 \text { patients, } \\
\text { endovascularly } \\
\text { treated aneurysms } \\
\text { from January } 2001 \text { to } \\
\text { December } 2012,\end{array}$ & $\begin{array}{l}\text { Ten of the aneurysms treated with } \\
\text { endovascular therapy demonstrated } \\
\text { perianeurysmal edema, mostly } \\
\text { asymptomatic }\end{array}$ & 838 \\
\hline Su IC & $\begin{array}{l}\text { retrospective } \\
\text { analysis }\end{array}$ & $\begin{array}{l}\text { Aneurysmal wall } \\
\text { enhancement and } \\
\text { perianeurysmal edema after } \\
\text { endovascular treatment } \\
\text { of unruptured cerebral } \\
\text { aneurysms }\end{array}$ & Neuroradiology & 2014 & & $\begin{array}{l}\text { wall enhancement } \\
\text { and perianeurysmal } \\
\text { edema on MRI } \\
\text { after endovascular } \\
\text { treatment were } \\
\text { analyzed }\end{array}$ & $\begin{array}{l}\text { Eighty-five }(64.4 \%) \text { aneurysms had } \\
\text { wall enhancement, and } 9(6.8 \%) \\
\text { aneurysms had perianeurysmal brain } \\
\text { edema }\end{array}$ & 124 \\
\hline White JB & Case & $\begin{array}{l}\text { But Did You Use HydroCoil? } \\
\text { Perianeurysmal Edema and } \\
\text { Hydrocephalus with Bare } \\
\text { Platinum Coils }\end{array}$ & $\begin{array}{l}\text { AJNR Am J } \\
\text { Neuroradiol. }\end{array}$ & 2008 & & Bare platinum coils & $\begin{array}{l}\text { headache, dysequilibrium, } \\
\text { abducens palsy, and internuclear } \\
\text { ophthalmoplegia. Hemorrhage. } \\
\text { Hydrocephalus }\end{array}$ & 2 \\
\hline $\begin{array}{l}\text { Ushikoshi } \\
\text { S }\end{array}$ & Case & $\begin{array}{l}\text { Aggravation of brainstem } \\
\text { symptoms caused by a large } \\
\text { superior cerebellar artery } \\
\text { aneurysm after embolization } \\
\text { by Guglielmi detachable coils- } \\
\text {-case report. }\end{array}$ & $\begin{array}{l}\text { Neurol Med } \\
\text { Chir (Tokyo) }\end{array}$ & 1999 & & $\begin{array}{l}\text { Guglielmi detachable } \\
\text { coils }\end{array}$ & $\begin{array}{l}\text { aggravation of right oculomotor nerve } \\
\text { paresis and left hemiparesis }\end{array}$ & 1 \\
\hline
\end{tabular}


Citation: Backhaus R, Kremmler L, Kirzinger L, Wendl C, Schlachetzki F (2017) Neurovascular Compression Syndrome after Coiling Intracranial Aneurysm. J Vasc Med Surg 5: 319. doi: 10.4172/2329-6925.1000319

Page 5 of 6

\begin{tabular}{|c|c|c|c|c|c|c|c|c|}
\hline Ozaki M & Case & $\begin{array}{l}\text { Delayed hydrocephalus after } \\
\text { embolization of unruptured } \\
\text { aneurysms using bare } \\
\text { platinum coils: report of } 2 \\
\text { cases }\end{array}$ & $\begin{array}{l}\text { AJNR Am J } \\
\text { Neuroradiol. }\end{array}$ & 2011 & $\begin{array}{l}\text { unruptured } \\
\text { intracranial } \\
\text { aneurysms }\end{array}$ & bare platinum coils & delayed hydrocephalus & 2 \\
\hline Mitha AP & Case & $\begin{array}{l}\text { Communicating } \\
\text { hydrocephalus after } \\
\text { endovascular coiling of } \\
\text { unruptured aneurysms: report } \\
\text { of } 2 \text { cases. }\end{array}$ & J Neurosurg. & 2008 & $\begin{array}{l}\text { unruptured } \\
\text { aneurysms }\end{array}$ & $\begin{array}{l}\text { endovascular coiling, } \\
\text { hydrogel-coated coils }\end{array}$ & $\begin{array}{l}\text { delayed communicating } \\
\text { hydrocephalus }\end{array}$ & 2 \\
\hline $\begin{array}{l}\text { Marchan } \\
\text { EM }\end{array}$ & Retrospective & $\begin{array}{l}\text { Hydrogel coil-related delayed } \\
\text { hydrocephalus in patients with } \\
\text { unruptured aneurysms. }\end{array}$ & J Neurosurg & 2008 & $\begin{array}{l}\text { unruptured } \\
\text { cerebral } \\
\text { aneurysms }\end{array}$ & $\begin{array}{l}\text { bare platinum }(n=26) \\
\text { and hydrogel coils } \\
(n=29)\end{array}$ & $\begin{array}{l}14 \% \text { incidence }(95 \% \text { confidence } \\
\text { interval } 3.9-31.7 \% \text { ) of symptomatic } \\
\text { hydrocephalus } 2-6 \text { months after the } \\
\text { intervention with hydrogel coils }\end{array}$ & 55 \\
\hline $\begin{array}{l}\text { Turner } \\
\text { RD }\end{array}$ & case & $\begin{array}{l}\text { Delayed visual deficits } \\
\text { and monocular blindness } \\
\text { after endovascular } \\
\text { treatment of large and giant } \\
\text { paraophthalmic aneurysms }\end{array}$ & Neurosurgery & 2008 & $\begin{array}{l}\text { paraophthalmic } \\
\text { region aneurysm }\end{array}$ & $\begin{array}{l}\text { coil embolization, } \\
\text { hydrogel-coated and } \\
\text { bare platinum coils }\end{array}$ & delayed onset of vision loss & 6 \\
\hline $\begin{array}{l}\text { Meyers } \\
\text { PM }\end{array}$ & Case & $\begin{array}{l}\text { Chemical meningitis after } \\
\text { cerebral aneurysm treatment } \\
\text { using two second-generation } \\
\text { aneurysm coils: report of two } \\
\text { cases. }\end{array}$ & Neurosurgery. & 2004 & $\begin{array}{l}\text { large cerebral } \\
\text { aneurysms }\end{array}$ & $\begin{array}{l}\text { second-generation } \\
\text { aneurysm coils }\end{array}$ & $\begin{array}{l}\text { evelopment of symptomatic } \\
\text { nonbacterial meningitis }\end{array}$ & 2 \\
\hline $\begin{array}{l}\text { Dönmez } \\
\mathrm{H}\end{array}$ & Case & $\begin{array}{l}\text { Stroke secondary to aseptic } \\
\text { meningitis after endovascular } \\
\text { treatment of a giant aneurysm } \\
\text { with parent artery occlusion }\end{array}$ & $\begin{array}{l}\text { Cardiovasc } \\
\text { Intervent } \\
\text { Radiol. }\end{array}$ & 2009 & giant aneurysm & bare platinum coils & $\begin{array}{l}\text { aseptic meningitis causing brain stem } \\
\text { and cerebellar infarct }\end{array}$ & 1 \\
\hline $\begin{array}{l}\text { Studley } \\
\text { MT }\end{array}$ & Case & $\begin{array}{l}\text { Delayed thromboembolic } \\
\text { events } 9 \text { weeks after } \\
\text { endovascular treatment of an } \\
\text { anterior communicating artery } \\
\text { aneurysm: case report. }\end{array}$ & $\begin{array}{l}\text { AJNR Am J } \\
\text { Neuroradio }\end{array}$ & 2002 & $\begin{array}{l}\text { anterior } \\
\text { communicating } \\
\text { artery aneurysm }\end{array}$ & $\begin{array}{l}12 \text { Guglielmi } \\
\text { detachable coils }\end{array}$ & Thromboembolic events, stroke & 1 \\
\hline
\end{tabular}

Table 1: Overview on literature.

neurological symptoms. In 1994 Van Halbach and Higash showed that endovascular treatment reduces a mass effect [19], whereas in 2004 Heran et al. reported the opposite, favouring surgical clipping in cases in which a mass effect was present [20]. Regarding critical anatomical locations, in 2011 Schuss et al. reported a small series of aneurysms affecting the visual system; these authors found that clipping could be superior to endovascular treatment in reducing a mass effect. Concerning treatment complications most available reports are cases describing clinical symptoms like seizures or symptoms of hydrozephalus after coiling. Three larger studies found post interventional wall enhancement and oedema of the coiled aneurysma in between 6.8 and $18.6 \%$ [21-35].

In summary, there are four main complications described in literature:

- Thrombembolism as a cause of stroke from aneurysmal neck

- Inflammatory response due to coiled and thrombosed aneurysma

- Mass effect

- Local inflammation by chemical ingredients or contamination of the coils. These cases emphasize again the necessity of multimodal treatment choices in patients with complicated aneurysms of the basilar artery that exert a mass effect, both with regard to the choice of treatment and the management of complications like seizures, perianuerysmal edema and hydrocephalus.

\section{Conclusion}

Local symptomatic perianeurysmal oedema with neurovascular compression syndrome is a rare complication of endovascular treatment and has to be considered when patients display neurological symptoms, especially in space-occupying aneurysms. The exact pathophysiology of this complication remains nebulous; however, contamination of the coil, thrombosis, local cytokine release by mechanical irritation and a specific reaction to the coil material may be responsible. Administration of corticosteroids, platelet inhibitors, and hyperosmolar therapy may be therapeutic and, overall, the long-term prognosis for these patients is good.

\section{Acknowledgment}

Author thanks Jo Ann M. Eliason, MA, ELS, for her assistance in the editing of this paper.

\section{Conflict of Interest}

The authors report no conflicts of interest related to this study or preparation of the paper.

\section{References}

1. Kwan ES, Heilman CB, Shucart WA, Klucznik RP (1991) Enlargement of basilar artery aneurysms following balloon occlusion--"water-hammer effect". Report of two cases. J Neurosurg 75: 963-968.

2. Horie N, Kitagawa N, Morikawa M, Tsutsumi K, Kaminogo M, et al. (2007) Progressive perianeurysmal edema induced after endovascular coil embolization. Report of three cases and review of the literature. J Neurosurg 106: 916-920.

3. Szikora I, Seifert P, Hanzely Z, KulcsarZ, Berentei Z, et al. (2006) Histopathologic evaluation of aneurysms treated with Guglielmi detachable coils or matrix detachable microcoils. AJNR Am J Neuroradiol 27: 283-288.

4. Molyneux AJ, Ellison DW, Morris J, Byrne VJ (1995) Histological findings in giant aneurysms treated with Guglielmi detachable coils. Report of two cases with autopsy correlation. J Neurosurg 83: 129-132.

5. Dai D, Ding YH, Kadirvel R, Danielson MA, Lewis DA, et al. (2006) A longitudinal immunohistochemical study of the healing of experimental aneurysms after embolization with platinum coils. AJNR Am J Neuroradiol 27: 736-741. 
Citation: Backhaus R, Kremmler L, Kirzinger L, Wendl C, Schlachetzki F (2017) Neurovascular Compression Syndrome after Coiling Intracranial Aneurysm. J Vasc Med Surg 5: 319. doi: 10.4172/2329-6925.1000319

6. Diegelmann RF, Evans MC (2004) Wound healing: an overview of acute fibrotic and delayed healing. Front Biosci 9: 283-289.

7. Dixon DA, Tolley ND, Bemis-Standoli K, Martinez ML, Weyrich SA, et al. (2006) Expression of COX-2 in platelet-monocyte interactions occurs via combinatoria regulation involving adhesion and cytokine signaling. J Clin Invest 116: 2727 2738.

8. Levi M, Van der Poll T (2005) Two-way interactions between inflammation and coagulation. Trends Cardiovasc Med 15: 254-259.

9. Stracke CP, Krings T, Möller-Hartmann W, Mahdavi A, Klug N, et al. (2007) Severe inflammatory reaction of the optic system after endovascular treatment of a supraophthalmic aneurysm with bioactive coils. AJNR Am J Neuroradiol 28: $1401-1402$

10. AL-Okaili R, Patel SJ (2002) Brain abscess after endovascular coiling of a saccular aneurysm: case report. AJNR Am J Neuroradiol 23: 697-699.

11. Skolarus LE, Gemmete JJ, Braley T, Morgenstern LB, Pandey A (2010) Abnormal white matter changes after cerebral aneurysm treatment with polyglycolic-polylactic acid coils. World Neurosurg 75: 640-644.

12. Pessin MS, Chimowitz MI, Levine SR, Kwan ES, Adelman LS, et al. (1989) Stroke in patients with fusiform vertebrobasilar aneurysms. Neurology 39: 16-21.

13. Passero S, Filosomi G (1998) Posterior circulation infarcts in patients with vertebrobasilar dolichoectasia. Stroke 29: 653-659.

14. Birchall D, Khangure MS, McAuliffe W (1999) Resolution of third nerve paresis after endovascular management of aneurysms of the posterior communicating artery. AJNR Am J Neuroradiol 20: 411-413.

15. Mavilio N, Pisani R, Rivano C, Testa V, Testa V, et al. (2000) Recovery of third nerve palsy after endovascular packing of internal carotid-posterior communicating artery aneurysms. Interv Neuroradiol 6: 203-209.

16. Ushikoshi S, Kikuchi Y, Houkin K, Miyasaka K, Abe H (1999) Aggravation of brainstem symptoms caused by a large superior cerebellar artery aneurysm after embolization by Guglielmi detachable coils--case report. Neurol Med Chir (Tokyo) 39: 524-529.

17. Tawk RG, Villalobos HJ, Levy El, Hopkins LN (2006) Surgical decompression and coil removal for the recovery of vision after coiling and proximal occlusion of a clinoidal segment aneurysm: technical case report. Neurosurgery 58: E1217.

18. Halbach VV, Higash (1994) The efficacy of endosaccular aneurysm occlusion in alleviating neurological deficits produced by mass effect. J Neurosurg 80 : 659-666.

19. Heran NS, Song JK, Kupersmith MJ, Niimi Y, Namba K, et al. (2007) Large ophthalmic segment aneurysms with anterior optic pathway compression assessment of anatomical and visual outcomes after endosaccular coil therapy. J Neurosurg 106: 968-975.

20. Schuss P, Güresir E, Berkefeld J, Seifert V, Vatter H, et al. (2011) Influence of surgical or endovascular treatment on visual symptoms caused by intracranial aneurysms: single-center series and systematic review. J Neurosurg 115: 694699.

21. Cohen JE, Itshayek E, Attia M, Moscovici S (2012) Postembolization perianeurysma edema as a cause of uncinate seizures. J Clin Neurosci 19: 474-476.

22. Vu Dang L, Aggour M, Thiriaux A, Kadziolka K, Pierot L (2009) Postembolization perianeurysmal edema revealed by temporal lobe epilepsy in a case of unruptured internal carotid artery aneurysm treated with bare platinum coils. J Neuroradiol 36: 298-300.

23. Craven I, Patel UJ, Gibson A, Coley SC (2009) Symptomatic perianeurysmal edem following bare platinum embolization of a small unruptured cerebral aneurysm. AJNR Am J Neuroradiol 30: 1998-2000.
24. Fanning NF, Willinsky RA, Ter Brugge KG (2008) Wall enhancement edema and hydrocephalus after endovascular coil occlusion of intradural cerebral aneurysms. J Neurosurg 108: 1074-1086.

25. Misaki K, Uchiyama N, Mohri M, Hirota Y, Hayashi Y, et al. (2010) Unusual delayed hydrocephalus after bare platinum coil embolization of an unruptured aneurysm. Neurol Med Chir (Tokyo) 50: 581-585

26. Marden FA, Ptman CM (2008) Perianeurysm edema with second-geneneration bioactive coils. Surg Neurol 69: 627-632.

27. Deus-Silva L, Lum C, De Meulemeester C, Dos Santos MP (2010) Severe inflammatory reaction of the optic system after endovascular treatment of coiling Neurosurgery 66: E222-E223

28. Sim KJ, Yan B, Dowling RJ, Mitchell PJ ( 2015) Intracranial aneurysms with perianeurysmal edema: long-term outcomes post-endovascular treatment. $J$ Neuroradiol. 4: 72-79

29. Su IC, Willinsky RA, Fanning NF, Agid R (2014) Aneurysmal wall enhancement and perianeurysmal edema after endovascular treatment of unruptured cerebral aneurysms. Neuroradiology 56: 487-495

30. White JB, Cloft HJ, Kallmes DF (2008) But did you use HydroCoil? Perianeurysmal edema and hydrocephalus with bare platinum coils. AJNR Am J Neuroradiol 29: 299-300.

31. Ushikoshi S, Kikuchi Y, Houkin K, Miyasaka K, Abe H (1999) Aggravation of brainstem symptoms caused by a large superior. cerebellar artery aneurysm after embolization by Guglielmi detachable coils--case report. Neurol Med Chir (Tokyo) 39: 524-529

32. Ozaki M, Murayama Y, Ebara M, Takao H, Abe T (2011) Delayed hydrocephalus after embolization of unruptured aneurysms using bare platinum coils: report of 2 cases. AJNR Am J Neuroradiol 32: E188-E1890.

33. Mitha AP, Wong JH, Lu JQ, Morrish WF, Hudon ME, et al. (2008) Communicating hydrocephalus after endovascular coiling of unruptured aneurysms: report of 2 cases. J Neurosurg 108: 1241-1244

34. Marchan EM, Sekula RF, Ku A, Williams R, O'Neill BR, et al. (2008) Hydrogel coil-related delayed hydrocephalus in patients with unruptured aneurysms. J Neurosurg 109: 186-190

35. Turner RD, Byrne JV, Kelly ME, Mitsos AP, Gonugunta V, et al. R008) Delayed visual deficits and monocular blindness after endovascular treatment of large and giant paraophthalmic aneurysms.Neurosurgery 63: 469-474 